Collection: COST Action FP0903 2010 - Rome (Italy)

"Research, monitoring and modelling in the study of climate change and air pollution impacts on forest ecosystems"

Guest Editors: E Paoletti, J-P Tuovinen, N Clarke, G Matteucci, R Matyssek, G Wieser, R

Fischer, P Cudin, N Pototic

\section{A new database for time-series monitoring data: the NitroEurope approach}

\author{
Owen $S M^{(1)}$, Leaver DS ${ }^{(1)}$, Bealey WJ ${ }^{(1)}$, Wilson $R^{(2)}$, Reis $S^{(1)}$, Sutton $M^{(1)}$
}

The NitroEurope Integrated Project (2006-2011) aimed to gain a better understanding of the nitrogen cycle and its impacts on the European greenhouse gas balance. Over sixty project partners collected large volumes of data from sites all over Europe. There are currently more than 15 forest sites in 11 countries, including beech, oak, spruce and mixed forests. The collected data are at different temporal resolutions, from one-off measurements to 30-minute timeseries data. Around 500 variables (plus attributes) are measured, including soil and plant data, details of cultivation management for natural and manipulated sites, long-term datasets of flux and concentrations of greenhouse gas and pollutants and their precursors, and micrometeorology data. The NitroEurope research community therefore needed a database to provide easy upload and extraction of data for analysis, interpretation and modelling. A bespoke database with a web-based graphical user interface (GUI) in a user-friendly and attractive online environment was produced by the NitroEurope (2011) database development team. The software provides a flexible interface between Microsoft Excel workbooks and an Oracle database. The database "Form Manager" enables construction of database forms which reflect the project's Excel data workbook templates. The software locates data according to Excel worksheet and cell references. The database "Uploader" extracts the specified data from completed Excel templates and uploads data directly to the Oracle relational database tables through the web front-end. Data are run through a series of automatic checks on upload which can be verified using an online graphing tool. Data are then validated and made available to the NitroEurope community for downloading. The database "Reporting" tools enable data from different sites and activities to be brought together and datasets can be previewed and graphed before they are downloaded. The database has almost 300 users and currently contains over eight million rows of data. The data will be made available to the wider scientific community two years after the project ends (Spring 2013). The database structure is extremely flexible and has been used for the storage and reporting of other time-series project data at our institute.

Keywords: Forest data, Greenhouse gas flux, Environmental data, Climate change, User-friendly on-line database

\section{Introduction}

It is well-known that the Nitrogen cycle is complex and that it impacts on the emissions of greenhouse gases (Vitousek et al. 1997). The NitroEurope (NEU) Integrated Project (2006-2011 - http://www.nitroeurope.eu/) addresses the questions "What is the effect of reactive nitrogen $\left(\mathrm{N}_{\mathrm{r}}\right)$ on the direction and magnitude of net greenhouse gas budgets for Europe?" and "To what extent would a more-integrated management of the N-cycle and its interactions with the C-cycle have the potential to reduce greenhouse gas and $\mathrm{N}$ emissions simultaneously?" (Sutton et al.
(1) Centre for Ecology \& Hydrology, Edinburgh, EH26 OQB (UK); (2) Modality Solutions Ltd., Edinburgh (UK)

@ Susan M. Owen (susa1@ceh.ac.uk)

Received: Jan 11, 2011 - Accepted: Aug 12, 2011

Citation: Owen SM, Leaver DS, Bealey WJ, Wilson R, Reis S, Sutton M, 2011. A new database for time-series monitoring data: the NitroEurope approach. iForest 4: 226 232 [online 2011-11-03] URL:

http://www.sisef.it/iforest/show.php? id $=595$

nitrogen and greenhouse gases observed in the field, their interactions and responses to global change and land-management decisions, through refinement of plot-scale models. At a larger spatial scale, "Component 4" quantifies multiple $\mathrm{N}$ and $\mathrm{C}$ fluxes for contrasting European landscapes using field measurements and modelling techniques, while "Component 5" is another modelling component, scaling up reactive nitrogen $(\mathrm{Nr})$ and net greenhouse gas fluxes for terrestrial ecosystems to regional and European levels. Finally, "Component 6" is concerned with verification of European $\mathrm{N}_{2} \mathrm{O}$ and $\mathrm{CH}_{4}$ inventories and refinement of the approaches of the International Panel on Climate Change (IPCC).

Because of the wide diversity of data generated by the NitroEurope project, none of the approaches already available for the handling and storage of datasets (e.g., simple Microsoft Access, the CarboEurope database, the British Atmospheric Data Centre) were able to satisfy the requirements for management of the NitroEurope Data. The solution to this challenge was to manage the data within three different data centres which can be accessed from the same page on the NitroEurope web portal (http://www.nitroeurope.eu/). The three data centres are the Centre for Ecology and Hydrology (CEH). UK; French National Institute for Agricultural Research (INRA), France, and the Joint Research Centre (JRC), Italy. Each centre operates a database: the "Component 1-3 database" at $\mathrm{CEH}$ for the field and manipulated plot measurements as well as the plot scale model output, the "Component 4 database" at INRA for landscape spatial and model data, and the "Components 5-6 database" at JRC for European scale modelling and validation data. The web portal is accessible to the public, but registration is required to view all the pages. Separate registration is also required for the three data centres to protect the Intellectual Property Rights (IPR) of scientists who have uploaded unpublished data. All data will be freely available in April 2013 (two years after the end 
Fig. 1 - Workflow for uploading, amending and accessing data on the NitroEurope C1-C3 Database of the project). As mentioned already, each component generates large volumes of many different types of data for four different ecosystem groups - Arable, Grassland, Forest and Wetlands and Shrublands. For example, field and manipulated plot measurements include one-off type data (including measuring site location and details), and data measured annually (such as vegetation cover, leaf area index (LAI) and above ground biomass) These activities also generate data which are collected at infrequent intervals (e.g., some

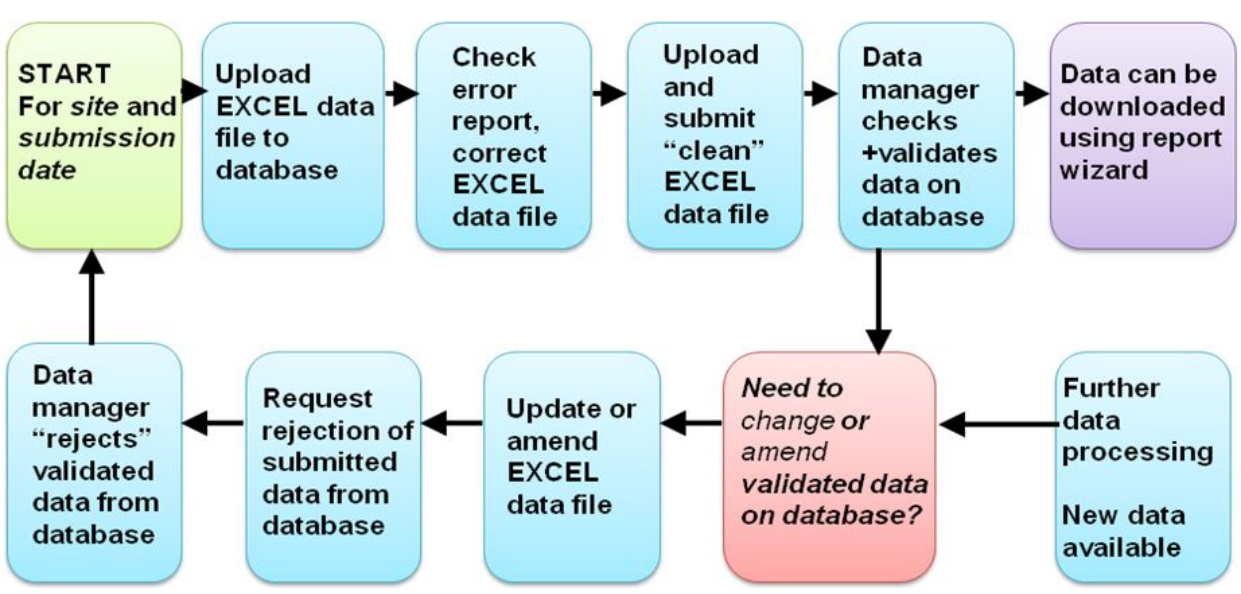

greenhouse gas flux, land management practices), and several types of data are collected at up the 30 minute intervals (including meteorological data, gas fluxes and concentrations). The plot-scale modelling component simulates the measurements made at field sites. All these data are stored on the NitroEurope "Component 1-3" database. The data management committee (DMC) manages the collection, storage and retrieval of data. The DMC comprises a chair-person and a data manager for each of the six science compo-

Tab. 1 - Data field categories for "Level 1" Inferential sites.

\begin{tabular}{|c|c|c|}
\hline Category of data & Examples of data fields & Units \\
\hline \multirow[t]{6}{*}{ Metadata } & Site id & text \\
\hline & Analysis Lab id & text \\
\hline & Month & text \\
\hline & Date/Time start and end of exposure & text \\
\hline & Volume sampled & $\mathrm{m}^{3}$ \\
\hline & Flow rate of sampling & $\mathrm{L} \min ^{-1}$ \\
\hline $\mathrm{NO}_{3}^{-}$raw data & $\begin{array}{l}\text { Lab blank, Denuder concs and capture efficiency } \\
\text { for } \mathrm{NO}_{3}^{-}\end{array}$ & $\mu \mathrm{g} \mathrm{NO}_{3}^{-}, \%$ \\
\hline $\begin{array}{l}\mathrm{HNO}_{3} \text { gaseous } \\
\text { concentrations }\end{array}$ & Results 1.2 .3 for calculating $\mathrm{HNO}_{3}$ & $\mu \mathrm{g} \mathrm{HNO}_{3} \mathrm{~m}^{-3}$ \\
\hline $\mathrm{NO}_{2}^{-}$raw data & $\begin{array}{l}\text { Lab blank, Denuder concs and capture efficiency } \\
\text { for } \mathrm{NO}_{2}^{-}\end{array}$ & $\mu \mathrm{g} \mathrm{NO}_{2}^{-}, \%$ \\
\hline $\begin{array}{l}\text { HONO gaseous } \\
\text { concentrations }\end{array}$ & Results 1.2 .3 for calculating $\mathrm{HONO}$ & $\mu \mathrm{g}$ HONO m ${ }^{-3}$ \\
\hline $\mathrm{SO}_{4}=$ raw data & $\begin{array}{l}\text { Lab blank, Denuder concs and capture efficiency } \\
\text { for } \mathrm{SO}_{4}=\end{array}$ & $\mu \mathrm{g} \mathrm{SO}_{4}=\%$ \\
\hline $\begin{array}{l}\mathrm{SO}_{2} \text { gaseous } \\
\text { concentrations }\end{array}$ & Results 1.2 .3 for calculating $\mathrm{SO}_{2}$ & $\mu \mathrm{g} \mathrm{SO}_{2} \mathrm{~m}^{-3}$ \\
\hline $\mathrm{Cl}^{-}$raw data & $\begin{array}{l}\text { Lab blank, Denuder concs and capture efficiency } \\
\text { for } \mathrm{Cl}^{-}\end{array}$ & $\mu \mathrm{g} \mathrm{Cl}, \%$ \\
\hline $\begin{array}{l}\mathrm{HCl} \text { gaseous } \\
\text { concentrations }\end{array}$ & Results 1.2 .3 for calculating $\mathrm{HCl}$ & $\mu \mathrm{g} \mathrm{HCl} \mathrm{m}{ }^{-3}$ \\
\hline $\mathrm{NH}_{4}^{+}$raw data & $\begin{array}{l}\text { Lab blank, Denuder concs and capture efficiency } \\
\text { for } \mathrm{NH}_{4}^{+}\end{array}$ & $\mu \mathrm{g} \mathrm{NH}_{4}^{+}, \%$ \\
\hline $\begin{array}{l}\mathrm{NH}_{3} \text { gaseous } \\
\text { concentrations }\end{array}$ & Results 1.2 .3 for calculating $\mathrm{NH}_{3}$ & $\mu \mathrm{g} \mathrm{NH}_{3} \mathrm{~m}^{-3}$ \\
\hline Denuder data flag & Denuder data flag & - \\
\hline Aerosol & $\begin{array}{l}\text { calculated and corrected } \mathrm{NO}_{3}^{-}, \mathrm{NO}_{2}^{-}, \mathrm{SO}_{4}=, \mathrm{Cl}^{-} \\
\mathrm{NH}_{4}^{+}\end{array}$ & $\begin{array}{c}\mu \mathrm{g} \mathrm{NO}_{3}^{-} \\
\left(\mathrm{NO}_{2}^{-}, \mathrm{SO}_{4}{ }^{-}, \mathrm{Cl}^{-},\right. \\
\left.\mathrm{NH}_{4}^{+}\right) \mathrm{m}^{-3}\end{array}$ \\
\hline Basic cations & $\mathrm{Ca}, \mathrm{Mg}, \mathrm{Na}$ & $\mu \mathrm{g} \mathrm{m}^{-3}$ \\
\hline Aerosol data flag & Aerosol data flag & - \\
\hline Comments & Comments & - \\
\hline
\end{tabular}

nents. Three of these data managers are also managers of the data centres. In addition, an external software contractor developed the software for datacentre C1-C3, and information expertise and IT support have been provided by the three data centres. It is was the Data Management Committee's responsibility to devise a Data Management Policy, a Data Management Plan which included data access and intellectual property rights issues, and to implement the software for the databases for storage and retrieval. This paper describes the data management for the NitroEurope science components dealing with field measurements, manipulated site measurements and plot scale modelling) and the database which was specifically designed for uploading and reporting these data.

\section{Materials and Methods}

All NitroEurope science components involve the collection and/or processing of large quantities of data, particularly those tasked with flux measurements, manipulation experiments and plot scale modelling which cover the highly time-resolved flux data, and the modelled simulations of plot fluxes.

A workflow was defined for the collection and uploading of data, which needed to account for the initial collection of data into Excel workbook templates at each of the study sites (Fig. 1). On the basis of this workflow, the Data Management Committee devised a protocol and technical specification for bespoke software to provide a userfriendly interface between the user and the Excel data templates, and an Oracle database. This software will be described in detail in a future publication (Owen et al. "A flexible new database system with easy storage and reporting of any time series data: the NitroEurope project application" - in preparation), and a brief overview is given here.

The database needed to handle the Microsoft Excel data templates which each site manager completes for uploading. The data are collected from more than 200 
Fig. 2 - Screenshots of Form-

Designer for the Nitro-

Europe C1-C3 Database.

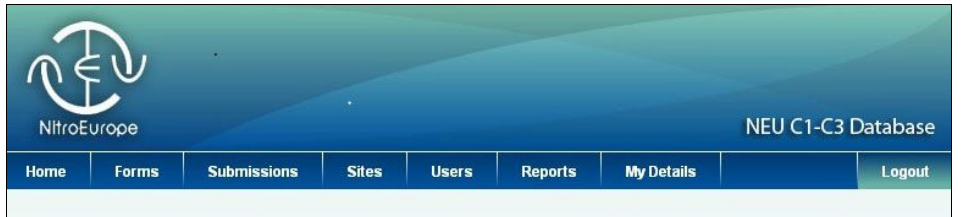

\section{Form Details}
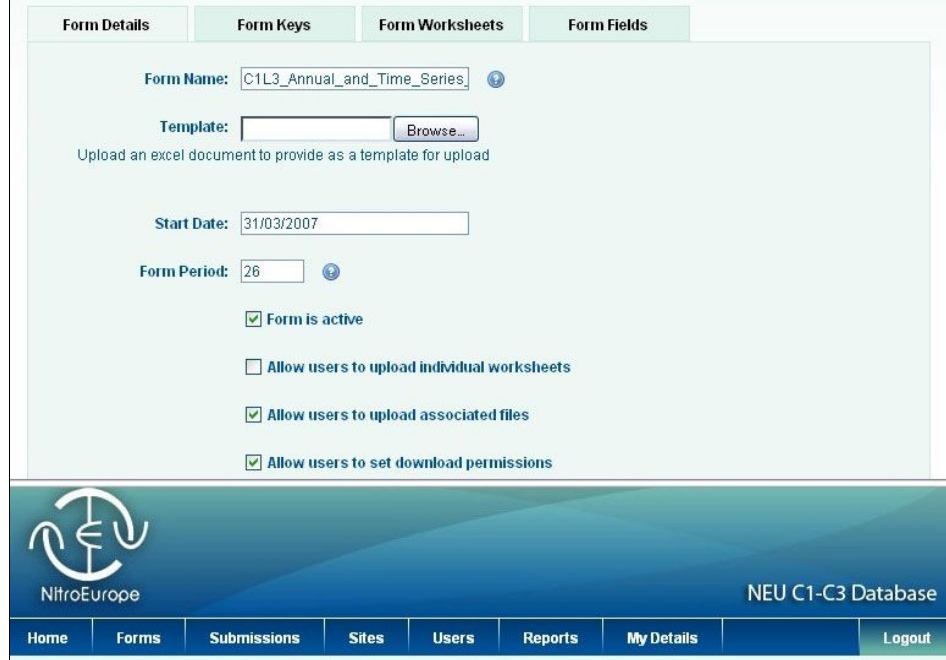

\section{- Form Details}

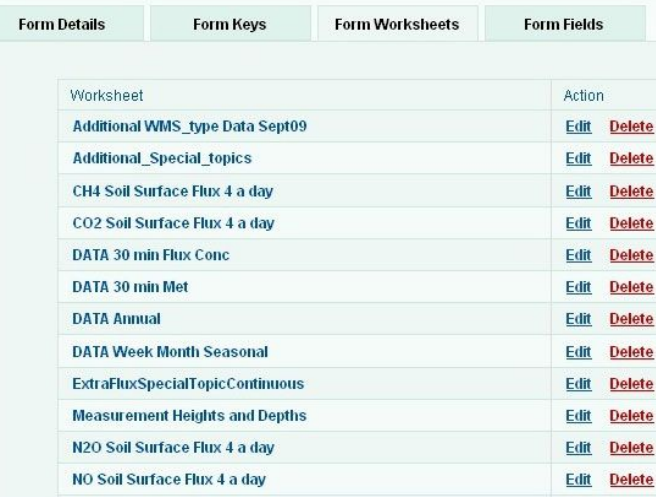

22 core manipulation sites and fourteen associated manipulation sites (drought, fertilization etc), where data for around 350 variables are collected (Appendix 3). Some data fields are mandatory, and others are optional. For each variable, its symbol, units, method, and frequency are defined to ensure consistency across sites, essential for bringing together data from different sites for analysis. However, although there is consistency for each data field across different sites, there are occasional discrepancies in units between component datasets (database "forms"). Because all downloaded data is headed by data field names and units, users are always aware of the units that have been used for the storage of any particular data field.

The database software was designed to accommodate different types of "users" with different roles: Form Manager, Data Uploader, Data Downloader (Owen et al., in preparation). The Form Manager role can use the Form Designer part of the web-based application to design the database Forms (Fig. 2). The software translates the form to construct the Oracle database table where the data are stored. The database Forms are based on the Excel workbook sheets of the data templates that the site managers complete. The structure of the database tables and the field names are thus completely recognisable to the user. The Database Form recognises the Excel workbook location of cell or column, and defines field format, unit type, if required, validation range, and any data attributes (Fig. 3). Date and time of measurement is a key field for all data. For Component 2 manipulation site data, the key field consists of a concatenation of date/ time, treatment, block and replicate. For some data types there are other key fields which additionally concatenate to generate the unique key identifier. The database scientists working at more than 80 sites across Europe. There are 50 "Level 1" inferential sites allowing the interpretation of measured $\mathrm{CO}_{2}$ fluxes in relation to inferential estimates of $\mathrm{N}$ supply and key soil variables, and nine "Level 2" regional sites using low-cost N flux methods as a basis to establish a future long-term flux monitoring capability at $\mathrm{CO}_{2}$ flux sites. Data for around 100 and 500 variables and attributes are collected at Level 1 and Level 2 sites, respectively (Tab. 1, Appendix 1). There are also thirteen "Level 3" Super Sites, with detailed investigation of $\mathrm{N}$ budgets/fluxes and interactions with carbon-cycling, supported by detailed plant and soil inventorying and process studies, where data for more than 500 variables and associated attributes (e.g., standard deviation, gap-filling flags) are collected (Appendix 2). In addition, there are

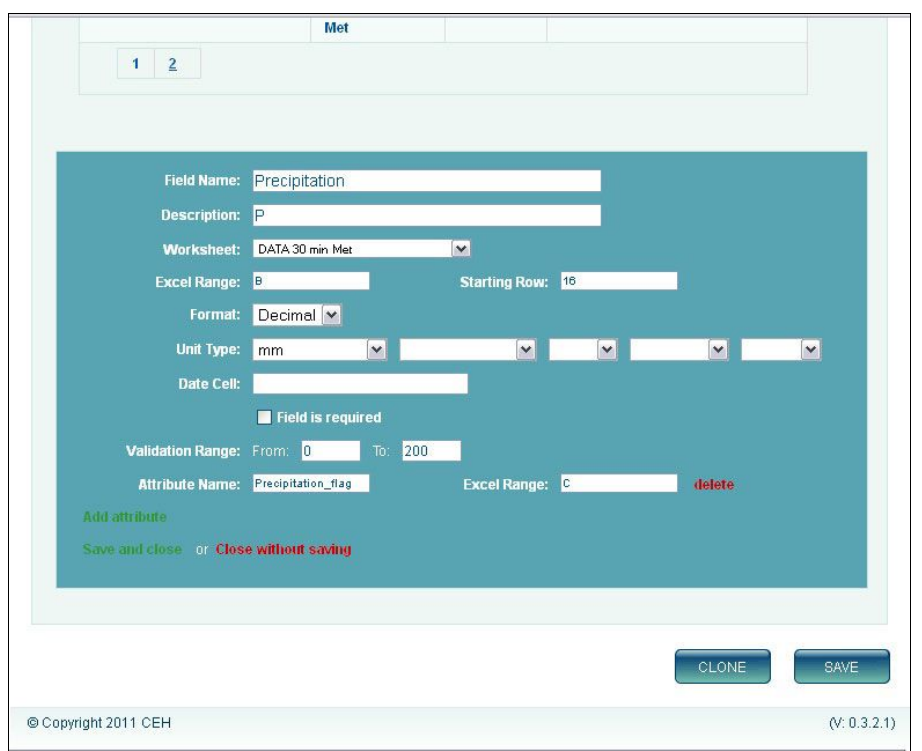

Fig. 3 - Defining a data field in FormDesigner for the NitroEurope C1C3 database. 
design software allows unlimited numbers of fields and key fields (within the Oracle Database system limitations).

Data are submitted to the database by uploading the completed Excel workbooks, in predefined date ranges (Fig. 4). The uploaded Excel data workbook is also stored on the fileserver. Each submission date range can be defined by the Form Manager, for example, a 6-month block of data was a convenient amount of data to collect and upload at one time for Level 3 sites, and so submission date deadlines were set every six months. Data are submitted by site by submission date deadline (e.g., twice a year). Any number of associated files can be uploaded with each submission, so that images, maps, model code etc. can be associated with the uploaded and reportable data.

The software performs automatic upload checks, for example some fields are "Required" and missing values are flagged, range of values expected for different fields (which can help indicate if the data are in the correct units), data type (e.g., text, numeric) and duplicate key-field value checks. The database generates a downloadable onscreen error report of problems detected in the dataset being uploaded. Data that need correcting or amending can be re-uploaded to the database. As with any database software, automatic checks cannot capture all data problems.

The software also provides a Report Wizard for user-friendly downloading of data. It is possible to select fields and attributes from any of the dataset forms. Data from different NitroEurope components can be combined. To run a report, it is necessary to select the required date range, the key field filters, the sites or ecosystem type. Results are displayed on screen, and data can be downloaded to Excel or CSV format (Fig. 5). There is an averaging feature which allows, e.g., 30 minute data to be averaged to hourly data, and then hourly data can be averaged to produce an average diurnal cycle (e.g., Fig. 6). In general, the "Frequency" reporting function can average, sum, or select $\mathrm{min} / \mathrm{max}$ values over a given time period. The "Grouping" reporting function can then display diurnal cycles and seasonal cycles. Automatic messaging informs data owners when and who downloaded their data. A user who has downloaded data that has been rejected and re-submitted, will receive an email suggesting that they re-download the data as it may have changed.

\section{Results}

A web-based, user-friendly database user interface with highly flexible uploading and reporting facilities has been developed which provides an easy interface between Excel data workbooks containing field and model data, and an Oracle database. The

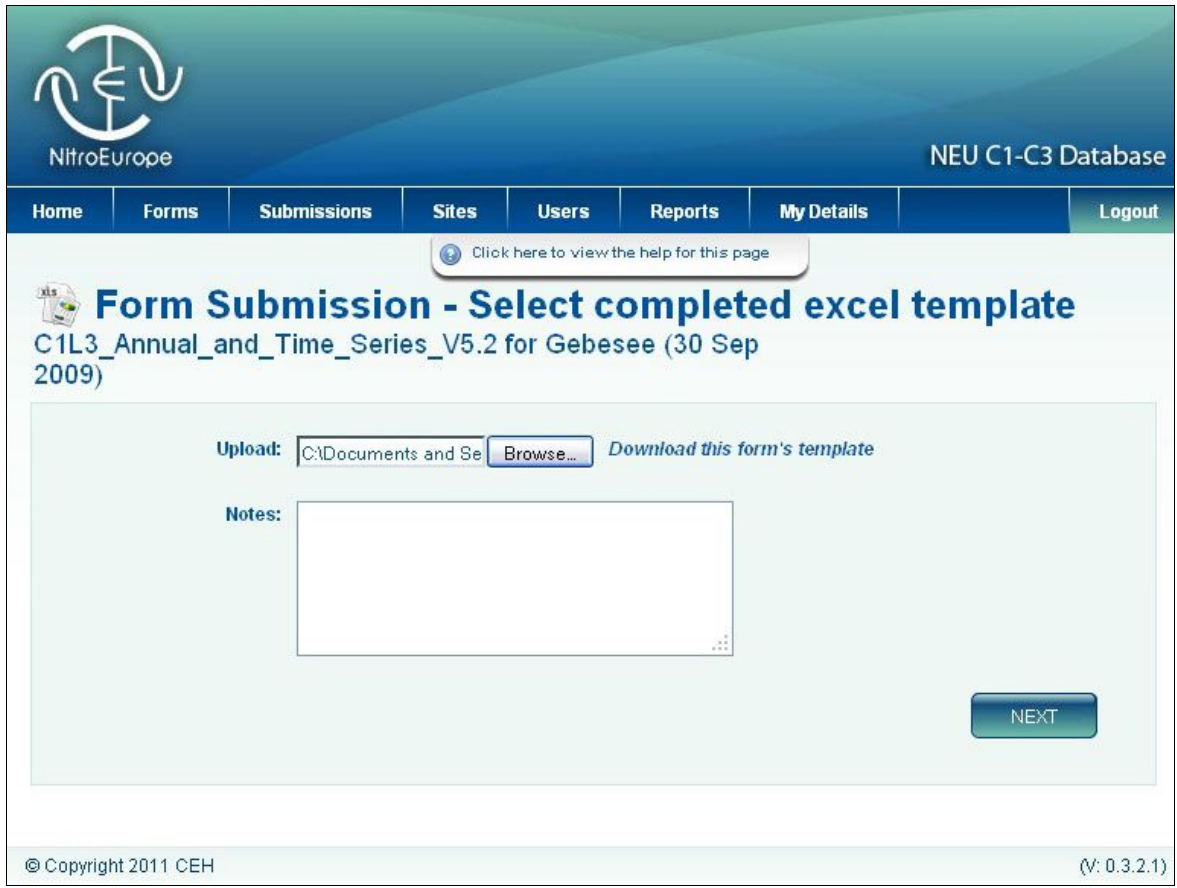

Fig. 4 - Uploading an Excel workbook. software was developed for NitroEurope Science components 1,2 and 3 and currently holds time series data for arable, grassland, forest, wetland and shrubland ecosystems. The forest sites which have data already uploaded to the database, or that will be uploaded before summer 2011, are listed in Tab. 2.

\section{送 C1 L3 Fluxes}

(V) Bugac BETWEEN 20 Dec 2006 AND 20 Jan 2009

\section{SAVE TO EXCEL}

With more than 80 measurement sites overall, more than 1000 data fields (variables + attributes) and high frequency of measurements for many of those variables, around 8 million rows of data have already generated in the database. At the time of writing, no data have yet been uploaded for the $\sim 50$ Level 1 inferential sites, but this is intended

\begin{tabular}{|l|l|l|l|l|l|l|}
\hline Bugac BETWEEN 20 Dec 2006 AND 20 Jan 2009 & \\
\hline SAVE TO EXCEL \\
\hline SITENAME
\end{tabular}

Fig. 5 - Example of tabular report output, downloadable to Excel or CSV. 
Fig. 6 - Example of graphical report output, showing grouping and frequency to produce an average diurnal cycle.

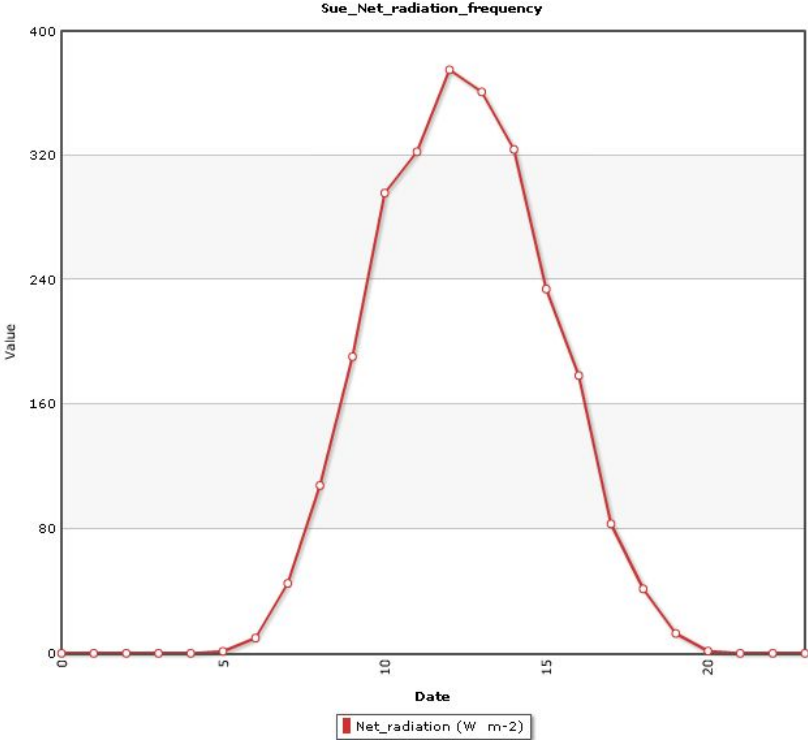

before the end of the NitroEurope project will be complete during the early months of (April 2011). Data have been uploaded for 2011. Most of the 13 "supersites" have upsome of the Level 2 regional sites, and this loaded time series data from Aug 2006 - Dec
2010, specifically the forest sites Soroe (Denmark), Hyytiala (Finland), Hoeglwald (Germany), Speulder (Netherlands). Most manipulated sites have also uploaded longterm data ("C2" sites - Tab. 2).

Because automatic data checks cannot capture all potential problems associated with huge datasets, NitroEurope organised two Data Quality exercises for Component 1, Level 3 supersite data. Different groups of data were checked across site by participating scientists. This exercise revealed gaps in data, wrong units which had not been detected by the value range checks, and a series of other problems within the large data sets that are inevitable in a project of this size. Each site then corrected their Excel data templates and re-uploaded to the database.

\section{Discussion and Conclusions}

Long-term storage and easy retrieval of field data at different spatial and temporal resolutions pose a challenge. The NitroEurope project is a large one, involving a community of nearly 300 scientists making

Tab. 2 - NitroEurope forest sites which have uploaded data (Dec 2010 - C1L2 = regional sites contributing to Component 1 field measurements; C1L3 = supersites contributing to Component 1 field measurements; 2 = manipulated sites contributing to Component 2 measurements).

\begin{tabular}{|c|c|c|c|c|c|}
\hline Site name & Label & Country & Forest Site & $\begin{array}{c}\text { Age } \\
\text { (years) }\end{array}$ & Location \\
\hline Soroe & C1L3 & Denmark & Beech dominated deciduous & 2500 & $\begin{array}{l}55^{\circ} 28^{\prime} \mathrm{N} \\
11^{\circ} 37^{\prime} \mathrm{E}\end{array}$ \\
\hline Hyytiala & C1L3 & Finland & Managed Scots Pine & 44 & $\begin{array}{l}61^{\circ} 51^{\prime} \mathrm{N} \\
24^{\circ} 17^{\prime} \mathrm{E}\end{array}$ \\
\hline Hoglwald & C1L3, C2 & Germany & Managed Norway Spruce & 110 & $\begin{array}{l}48^{\circ} 30^{\prime} \mathrm{N} \\
11^{\circ} 10^{\prime} \mathrm{E}\end{array}$ \\
\hline Speulder & C1L3 & Netherlands & Managed Douglas Fir & 46 & $\begin{aligned} 52^{\circ} 13^{\prime} \mathrm{N} \\
5^{\circ} 39^{\prime} \mathrm{E}\end{aligned}$ \\
\hline Klausenleopoldsdorf & $\mathrm{C} 2$ & Austria & Beech & $\sim 60$ & $\begin{array}{l}48^{\circ} 07^{\prime} \mathrm{N} \\
16^{\circ} 02^{\prime} \mathrm{E}\end{array}$ \\
\hline Achenkirchen & $\mathrm{C} 2$ & Austria & Spruce/Beech & $\sim 130$ & $\begin{array}{l}47^{\circ} 34^{\prime} \mathrm{N} \\
11^{\circ} 39^{\prime} \mathrm{E}\end{array}$ \\
\hline Alptal & $\mathrm{C} 2$ & Switzerland & Norway spruce/Silver Fir & $\sim 250$ & $\begin{array}{r}47^{\circ} 03^{\prime} \mathrm{N} \\
8^{\circ} 43^{\prime} \mathrm{E}\end{array}$ \\
\hline Klosterhede & $\mathrm{C} 2$ & Denmark & Oak, former Apple & $\sim 30$ & $\begin{aligned} 56^{\circ} 29^{\prime} \mathrm{N} \\
8^{\circ} 24^{\prime} \mathrm{E}\end{aligned}$ \\
\hline Stroedam & $\mathrm{C} 2$ & Denmark & Beech/Birch & $>200$ & $\begin{array}{l}55^{\circ} 57^{\prime} \mathrm{N} \\
12^{\circ} 17^{\prime} \mathrm{E}\end{array}$ \\
\hline Tolfa & $\mathrm{C} 2$ & Italy & Mediterranean evergreen - Arbutus unedo & - & $\begin{array}{l}42^{\circ} 10^{\prime} \mathrm{N} \\
11^{\circ} 55^{\prime} \mathrm{E}\end{array}$ \\
\hline Gårdsjön & $\mathrm{C} 2$ & Sweden & Norway spruce with some Scots Pine & $\sim 120$ & $\begin{array}{l}58^{\circ} 04^{\prime} \mathrm{N} \\
12^{\circ} 01^{\prime} \mathrm{E}\end{array}$ \\
\hline Skogaryd & $\mathrm{C} 2$ & Sweden & Norway spruce & $\sim 60$ & $\begin{array}{l}58^{\circ} 23^{\prime} \mathrm{N} \\
12^{\circ} 09^{\prime} \mathrm{E}\end{array}$ \\
\hline Fyodorovskoe & C1L2 & Russia & Picea abies $87 \%$; Betula pendula $13 \%$ & 181 & $\begin{array}{l}56^{\circ} 27^{\prime} \mathrm{N} \\
32^{\circ} 55^{\prime} \mathrm{E}\end{array}$ \\
\hline Vestskoven & $\mathrm{C} 2$ & Denmark & Oak, former Apple & $\sim 30$ & $\begin{array}{l}55^{\circ} 41^{\prime} \mathrm{N} \\
12^{\circ} 21^{\prime} \mathrm{E}\end{array}$ \\
\hline Falköping & $\mathrm{C} 2$ & Denmark & Betula pendula & $\sim 50$ & $\begin{array}{l}58^{\circ} 20^{\prime} \mathrm{N} \\
13^{\circ} 30^{\prime} \mathrm{E}\end{array}$ \\
\hline Herdada de Mitra & $\mathrm{C} 2$ & Portugal & Quercus suber, Quercus rotundifolia & - & $\begin{array}{l}38^{\circ} 32^{\prime} \mathrm{N} \\
7^{\circ} 54^{\prime} \mathrm{W}\end{array}$ \\
\hline Griffin & C1L2 & UK & Sitka Spruce & 20 & $\begin{aligned} 56^{\circ} 37^{\prime} \mathrm{N} \\
3^{\circ} 47^{\prime} \mathrm{W} \\
\end{aligned}$ \\
\hline
\end{tabular}


measurements which generate data for more than 1000 database fields. Microsoft Excel templates, although they have some intrinsic problems which are discussed below, are perhaps the most accessible format which most scientists are familiar with Excel templates were therefore used for initial data collection, and the database software was designed to use Excel templates as input, though the software is flexible enough to have the potential to accept other formats in future developments. The advantages of using Excel templates as input are familiarity, flexibility, no special software is needed to create the input worksheets, and full information and metadata can be provided within an Excel workbook. There are two main problems that have been encountered in the use of Excel as the input medium for the NitroEurope database. Firstly, there are some anomalies with date handling in Excel. The displayed date may be different to the real, stored date. Secondly, invalid characters are allowed to occur in numeric columns. Each of these problems are likely to be captured on upload, but duplicate date errors which can be generated from date storage anomalies in Excel can be hard to detect, especially as there can be problems with upward compatibility of workbook macros in new versions of Excel.

Because automatic upload checks cannot detect all problems associated with large time series datasets, it is necessary to perform further data quality analyses of different groups of data residing on the database Excellent examples are provided by the CarboEurope project (e.g., Göckede et al. 2008, Mauder et al. 2008). This type of analysis is outside the scope of the work presented here, but is addressed in ongoing and future data management and data quality activities in the NitroEurope project.

Data are available to all NitroEurope Community members for the duration of the project. Members must agree to the conditions of use for the data before downloading data Site Principal Investigators (PIs) are notified by email when a user has downloaded data from their site. The downloader receives an email with a reminder of the conditions of use and the names and email addresses of the PIs of the data downloaded to encourage communication with the PI. The IPR agreement reminds data downloaders that the data were generated or collected within the framework of the NitroEurope Integrated Project (IP) and that the user agrees (i) to restrict the use of the data to the context of the research topic specified at the time of the application, when this application was made to access data still restricted from the public domain; (ii) not to disclose the data to other parties; (iii) not to use the data for commercial purposes; (iv) that the Intellectual Property Right remains with the Data Origina- tor; (v) to contact the Data Originator prior to any use of the data; (vi) to offer the Data Originator(s) co-authorship of any publication or communication based on NitroEurope IP data; in the event that the offer is declined or when the Data Originators cannot be contacted, Data Originators must be duly acknowledged.

The NitroEurope project has already generated a number of publications, some of which are gathered into special issues (e.g., Agriculture, Ecosystems and Environment 133 (3-4) - 2009, European Journal of Soil Science 61(5) - 2010). Many of these publications are case studies, or preliminary syntheses. For example, Skiba et al. (2009) compared high resolution fluxes across ecosystems of $\mathrm{N}_{2} \mathrm{O}$, $\mathrm{NO}$ (also $\mathrm{CH}_{4}, \mathrm{CO}_{2}$ ) fluxes, wet and dry $\mathrm{N}$ deposition, leaching of $\mathrm{N}$ and $\mathrm{C}$ and $\mathrm{N}$ transformations in plant, litter and soil for the first 11 months of the project $(1 / 8 / 2006$ to $30 / 6 / 2007)$, and concluded that of the four ecosystems (grassland, arable, forest and wetland/shrubland), grasslands are the largest source of $\mathrm{N}_{2} \mathrm{O}$, forests are the largest source of $\mathrm{NO}$ and sink of $\mathrm{CH}_{4}$ and that $\mathrm{N}$ deposition rates influence $\mathrm{NO}$ and $\mathrm{N}_{2} \mathrm{O}$ fluxes in non-agricultural ecosystems. Ammann et al. (2009) focussed on a longer time-series of data from CarboEurope and the early NitroEurope measurements, studying greenhouse gas budgets by measuring $\mathrm{C}$ and $\mathrm{N}$ exchange on the field scale at the grassland site Oensingen over a 6-year period (2002-2007). Analysing Component 1 Level 1 site measurements (Tab. 1) for the first year of NitroEurope, Tang et al. (2009) reported an intercomparison of the European scale DELTA low-cost equipment by six participating laboratories at four test sites, demonstrating good agreement between different climatic conditions. The first year of measurements showed substantial spatial variability in atmospheric $\mathrm{Nr}$ concentrations, illustrating the major local $\left(\mathrm{NH}_{3}\right)$ and regional $\left(\mathrm{HNO}_{3}, \mathrm{NO}_{3}^{-}\right.$, and $\left.\mathrm{NH}_{4}^{+}\right)$differences in $\mathrm{Nr}$ concentrations, providing a basis to develop future estimates of site-based $\mathrm{Nr}$ dry deposition fluxes across Europe, and highlighting the role of agricultural $\mathrm{NH}_{3}$ as the largest single $\mathrm{Nr}$ constituent dominating dry $\mathrm{Nr}$ fluxes at most sites. Schaufler et al. (2010) reported a laboratory study to estimate potential greenhouse gas (nitrous oxide $\mathrm{N}_{2} \mathrm{O}$, nitric oxide $\mathrm{NO}$, carbon dioxide $\mathrm{CO}_{2}$ and methane $\mathrm{CH}_{4}$ ) flux rates from soils under different land use and climate, assessing the effect of soil temperature and soil moisture. They found a non-linear increase of $\mathrm{N}_{2} \mathrm{O}$, NO and $\mathrm{CO}_{2}$ emissions with increasing temperature, positive correlation of nitrous oxide emissions with soil moisture, and negative correlation of $\mathrm{NO}$ emission and $\mathrm{CH}_{4}$ oxidation rates with soil moisture. They showed that nitrous oxide and $\mathrm{CO}_{2}$ emissions were highest in grassland soils, while
NO emissions were highest in forest soils. These reports are a small sample of the type of study already published from the NitroEurope project. The project ends in Spring 2011 and therefore it is anticipated that a large number of synthesis papers will be written and published. Analyses and interpretation can now be extended to make use of the full 4.5 years of NitroEurope data, within and between sites and ecosystems. The data can also contribute to model input and validation, for example, Flechard et al. (2011) used NitroEurope data in their recently published a comparison of inferential models predicting dry deposition across Europe. The NitroEurope C1-C3 database will facilitate this effort across the board, by providing a central repository of all the field data, and a user-friendly reporting tool for accessing the data across components and work packages.

The database will be maintained beyond the end of NitroEurope and data will be made publically available two years after $\mathrm{Ni}$ troEurope has ended. Certain datasets can still be restricted to certain groups of users if required, but permission can be sought (via the database software) to gain access to restricted datasets. Data reporting is essentially simple, based on a report wizard. However, when the database is released to the general science community, non-NitroEurope scientists will need to refer to the reporting manual to identify which data fields of the hundreds available, might be of interest to them. This will be downloadable from the NitroEurope web site http://www.nitroeurope.eu.

The flexibility of database structure enables the database to be used for most time-series data and two other projects within CEH are already using the database software. There are plans to link the NitroEurope database to other European databases to further increase access to high-quality climate change-related data. These plans will be realised in the $\mathrm{CEH}$ project "Environment and Climate interactions - Observations and Responses in Ecosystems" (ENCORE) which started in 2011.

\section{Acknowledgements}

We gratefully acknowledge the contribution of the EU and national funding sources to the NitroEurope Integrated Project. We thank the NitroEurope Research Community, especially field scientists and site managers for the hard work and collaborative effort in preparing and uploading their field data. We thank Mark Sutton (the NitroEurope Project Leader), and the NitroEurope Secretariat for managing the project. It has been a privilege to be involved.

\section{References}

Ammann C, Spirig C, Leifeld J, Neftel A (2009). Assessment of the nitrogen and carbon budget of two managed temperate grassland fields. Agri- 
culture, Ecosystems \& Environment 133 (3-4): 150-162. - doi: 10.1016/j.agee.2009.05.006

Beier C, Skiba U, Sutton MA (2010). Guest Editor's Introduction: Greenhouse gas exchange in European ecosystems and their interactions with nitrogen - results from NitroEurope IP. European Journal of Soil Science 61 (5): 627-630. - doi: 10.1111/j.1365-2389.2010.01281.x

Dolman AJ, Tolk L, Ronda R, Noilhan J, Sarrat C, Brut A, Piguet B, Durand P, Butet A, Jarosz N, Brunet Y, Loustau D, Lamaud E, Miglietta F, Gioli B, Magliulo V, Esposito M, Gerbig C, Körner S, Glademard P, Ramonet M, Ciais P, Neininger B, Hutjes RW, Elbers JA, Macatangay R, Schrems O, Pérez-Landa G, Sanz MJ, Scholz Y, Facon G, Ceschia E, Beziat P (2006). The CarboEurope Regional Experiment Strategy. Bulletin of the American Meteorological Society 87 (10): 1367-1379. - doi: 10.1175/BAMS-8710-1367

Flechard CR, Nemitz E, Smith RI, Fowler D, Vermeulen AT, Bleeker A, Erisman JW, Simpson D, Zhang L, Tang YS, Sutton MA (2011). Dry deposition of reactive nitrogen to European ecosystems: a comparison of inferential models across the NitroEurope network. Atmospheric Chemistry and Physics 11 (6): 2703-2728. - doi: 10.5194/acp-11-2703-2011

Göckede M, Foken T, Aubinet M, AurelaM, Banza J, Bernhofer C, Bonnefond JM (2008). Quality control of CarboEurope flux data - Part I: Footprint analyses to evaluate sites in forest eco- systems. Biogeosciences 5(2): 433-450. - doi: 10.5194/bg-5-433-2008

Mauder M, Foken T, Clement R, Elbers JA, Eugster W, Grünwald T, Heusinkveld B, Kolle O (2008). Quality control of CarboEurope flux data - Part II: Inter-comparison of eddy-covariance software. Biogeosciences 5 (2): 451-462. - doi: 10.5194/bg-5-451-2008

NitroEurope (2011). Web portal "NitroEurope IP: The nitrogen cycle and its influence on the European greenhouse gas balance" [online] URL: http://www.nitroeurope.eu/

Schaufler G, Kitzler B, Schindlbacher A, Skiba U, Sutton MA, Zechmeister-Boltenstern S (2010). Greenhouse gas emissions from European soils under different land use: effects of soil moisture and temperature. European Journal of Soil Science 61 (5): 683-696. - doi: 10.1111/j.13652389.2010.01277.x

Skiba U, Drewer J, Tang Y, van Dijk N, Helfter C, Nemitz E, Famulari D, Cape J, Jones S, Twigg M (2009). Biosphere-atmosphere exchange of reactive nitrogen and greenhouse gases at the NitroEurope core flux measurement sites: Measurement strategy and first data sets. Agriculture, Ecosystems \& Environment 133 (34): 139-149. - doi: 10.1016/j.agee.2009.05.018 Sutton M, Nemitz E, Erisman J, Beier C, Bahl K, Cellier P, Devries W, Cotrufo F, Skiba U, Dimarco C (2007). Challenges in quantifying biosphere-atmosphere exchange of nitrogen species. Environmental Pollution 150 (1): 125-139. - doi: 10.1016/j.envpol.2007.04.014

Tang Y, Simmons I, van Dijk N, Di Marco C, Nemitz E, Dämmgen U, Gilke K, Djuricic V, Vidic S, Gliha Z (2009). European scale application of atmospheric reactive nitrogen measurements in a low-cost approach to infer dry deposition fluxes. Agriculture, Ecosystems \& Environment 133 (3-4): 183-195. - doi: 10.1016/j.agee.2009.04.027

Vitousek PM, Aber JD, Howarth RW, Likens GE, et al. (1997). Human alteration of the global nitrogen cycle: Sources and consequences. Ecological Applications 3: 737-750. [online] URL: http://pangea.stanford.edu/research/matsonlab/m embers/PDF/VitousekMatson1997_EcologicalApplications7.pdf

\section{Supplementary Material}

Appendix 1 - Data fields for "Level 2" Regional low-cost sites.

Link: Owen_595@supp1001.pdf

Appendix 2 - Data fields for NitroEurope component 1 (field measurements) "Level 3" Super-sites.

Link: Owen_595@supp1002.pdf

Appendix 3 - Data fields for NitroEurope Component 2 ("manipulated sites").

Link: Owen 595@suppl003.pdf 